\section{Information effects on cautious and}

$$
\text { risky-shift items }{ }^{1}
$$

PETER MURDOCH, Smith Richardson Foundation, P.O. Box 3265, Greensboro, N.C. 27402, DAVID G. MYERS, Hope College, Holland, Mich. 49423, and GENE F. SMITH, University of Iowa, Iowa City, lowa 52240

Mere exchange of information about others' initial judgments on choice dilemma items was predicted to yield shifts to risk or caution. In an information-exchange condition, 14 fouror five-man groups made choice dilemma judgments, displayed them, then remade their judgments. In a test-retest condition, 10 four- or five-man groups made choice dilemma judgments then remade them. Contrary to prediction, no significant shifts were found in the information-exchange condition, but significant shifts were found in the test-retest condition.

In many studies, group discussion has been observed to foster riskiness (Kogan \& Wallach, 1967). However, in some studies (e.g., Myers, Murdoch, \& Smith, in press; Vidmar, in press), group discussion fostered caution. Most studies have employed choice dilemma items (Kogan \& Wallach, 1964, Appendix E) on which S makes judgments of risk. After individual judgments on the items, Ss form groups to discuss their judgments. A shift is defined by the difference between the mean risk level of individual judgments and the mean after group discussion. A positive difference indicates a risky shift, while a negative difference indicates a cautious shift.

The most widely accepted of the current explanations of shift are based on the hypothesis that risky shift occurs when risk is culturally valued, and cautious shift occurs when caution is valued (Nordh $\phi y$, 1962). A definition of value in terms of initial judgment means has been proposed because of a significant relationship between initial judgment mean on an item and the mean amount of risky shift (Myers, 1967; Teger \& Pruitt, 1967). Brown (1965) has suggested, and Levinger \& Schneider (1969), Stoner (1968), Wallach \& Wing (1968) have confirmed, that many people mistakenly believe they are higher than their peers on the value engaged. One function of discussion is to provide information that exposes the mistaken beliefs. Hence, mere information about other people's judgments may stimulate shifts. Wallach \& Kogan (1965) tested the information exchange hypothesis by having groups display their judgments (without discussion) until consensus was achieved. No significant shifts were observed. However, Teger \& Pruitt (1967) have argued that a consensus requirement and demand characteristics of the instructions may have favored averaging of initial judgments. Teger and Pruitt changed these aspects and obtained significant shifts. Unfortunately, part of their instructions may have introduced a demand for shifting ("Consider what you are doing as a form of discussion ... Remember, if this were the usual form of discussion, many of you would change your answers for various reasons during the course of the discussion" p. 195). Also, three rounds of information exchange may have stimulated familiarization with the items, which may be sufficient to produce a shift (e.g., Bateson, 1966).

In this experiment, the minimal sufficient conditions for an information-exchange effect were provided-no discussion and one round of information exchange.

\section{SUBJECTS AND MATERIALS}

Females in introductory psychology classes at the University of Iowa chose to participate as a way of satisfying a course requirement. There were 10 five-person and 4 four-person information-exchange groups and 5 five-person and 5 four-person control groups.

The three cautious and the three risky items of Experiment 1 (Myers, Murdoch, \& Smith, in press) were used. Previous research has shown that discussion reliably results in the shift specified for the items. A sample cautious item is presented below.

Betty, a newlywed, has been informed by her physician that a heart ailment makes it inadvisable for her to have children. Having been an only child, Betty had always hoped to raise a large family herself. The physician suggests that a delicate medical operation could be attempted which, if successful, would completely relieve the heart condition. But its success could not be assured and, in fact, the operation might prove fatal.

Imagine that you are advising Betty. Listed below are several probabilities or odds that the operation will prove successful.

PLEASE CHECK THE LOWEST PROBABILITY THAT YOU WOULD CONSIDER ACCEPTABLE FOR THE OEPRATION TO BE PERFORMED.
The chances are 0 in 10 that the operation will be a success (i.e., the operation is certain not to be a success).

The chances are 1 in 10 that the operation will be a success.

The chances are 2 in 10 that the operation will be a success.

The chances are 3 in 10 that the operation will be a success.

The chances are 4 in 10 that the operation will be a success.

The chances are 5 in 10 that the operation will be a success.

The chances are 6 in 10 that the operation will be a success.

The chances are 7 in 10 that the operation will be a success.

The chances are 8 in 10 that the operation will be a success.

The chances are 9 in 10 that the operation will be a success.

The chances are 10 in 10 that the operation will be a success (i.e., the operation is certain to be a success).

\section{PROCEDURE}

The Ss were seated around a rectangular table, and $\mathrm{E}$ distributed the initial questionnaire containing instructions and the items (in random order for each group). After completing the questionnaires, Ss were assigned to the information exchange or the control condition.

In the information-exchange condition, $E$ distributed new questionnaries and $4 \times 6$ cards $(10.16 \times 21.24 \mathrm{~cm})$. He then read instructions for exchanging information. The first $S$ was requested to display her initial judgment on a card. The second $S$ was then requested to display her judgment and so on. After the last $S$ had displayed her initial judgment on an item, Ss were asked to make another judgment on it. They were reminded that in making their final judgments they were not bound in any way by their initial judgments. The Ss indicated their final judgments before continuing to the next item. Information exchange was begun with a different $S$ on each item.

In the control condition, $\mathbf{E}$ distributed new questionnaires. He then read instructions requesting $S s$ to reconsider their initial judgments without feeling bound by them.

Table 1 presents the mean initial judgments and the mean shift on risky and cautious items for the two conditions. The prediction from the information-exchange hypothesis is a greater risky shift on risky items and a greater cautious shift on cautious items in the information exchange than in the control condition. An analysis 
Table 1

Mean Risky Shitt for Each Item and Condition

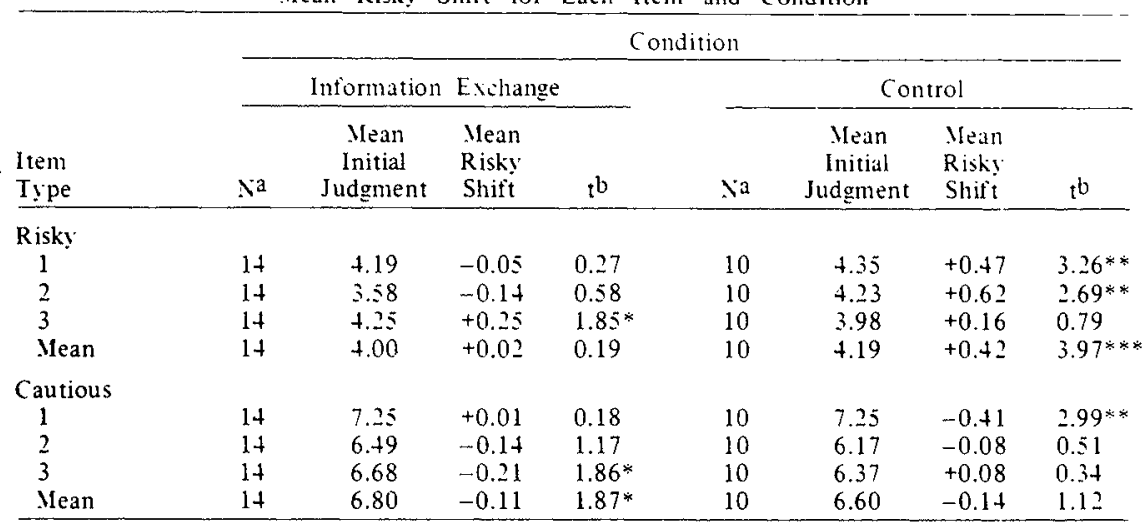

a Vumber of groups: $b$ To establish if shifts differ from zero

${ }^{*} p<.10$. no.tailed: ${ }^{* *} p<.05$. nio-tailed: $* * * p<.01$. mo-tailed

of variance was done on group shift scores to evaluate the predicted interaction between item type (a within-Ss variable) and condition (a between-Ss variable). Besides a significant item type main effect $(\mathrm{F}=13.18, \mathrm{df}=1 / 22, \mathrm{p}<.01)$, there was a significant Item Type by Condition interaction effect $(\mathrm{F}=6.10, \mathrm{df}=1 / 22$, $\mathrm{p}<.05$ ) which was opposite to prediction. The obtained differences in shifts on risky and cautious items were greater for the control than for the information exchange condition (Table 1).

In risky shift research it is customary to use $t$ tests to determine if mean shifts differ from zero (Table 1). According to the information-exchange hypothesis, there should be a cautious shift on cautious items and a risky shift on risky items in the information exchange condition but not in the control condition. Only limited support was found for the hypothesis. In the information condition there were supporting trends $(p<.10)$ on one risky item, one cautious item, and on the mean of cautious items. Moreover, in the control condition there were unexpected significant shifts $(\mathrm{p}<.05$ or better) on two risky items, the mean of risky items, and one cautious item.

\section{DISCUSSION}

The information-exchange hypothesis concerning shift was directly tested by providing minimal sufficient conditions for exchange of information concerning others' initial judgments. The data replicated the previous Wallach \& Kogan (1965) finding of no significant shift when information about others' initial judgments is provided. Mere knowledge of others' judgments may play a role in discussion conditions where Ss may feel freer to forsake their initial commitment than in the present setting. However, it is more likely that discussion produces shifts by other processes, such as providing new

reasons for moving toward the cultural value of an item (Brown, 1965).

The finding of significant shifts in the control condition replicated a previous finding (Myers, Murdoch, \& Smith, in press). It reiterates the suggestion that investigators use group data as a baseline for evaluating the additional effects of experimental treatments involving groups. REFERENCES

BATESON, N. Familiarization, group discussion. and risk-taking. Journal of Experimental Social Psychology, 1966, 2, 119-129.

BROWN, R. Social psychology. New York: The Free Press, 1965.

KOGAN, N., \& WALLACH, M. A. Risk taking: $A$ study in cognition and personality. New York: Holt, Rinehart, \& Winston, 1964.

KOGAN, N.. \& WALLACH, M. A. Risk taking as

\section{E. DOROSH, J. E. TONG, and D. R. BOISSONNEAULT, University of Guelph, Guelph, Ontario, Canada}

Two signal-detection procedures were used to parcel out the effects of white noise and instructions with a two-flash discrimination task. Neither condition influenced the sensitivity scores of either model. Variations in instructions changed the criterion and threshold measures. High correlation coefficients were obtained for the corresponding scores of the two signal-detection analyses.

Recent papers indicate a relationship between physiological measures of "arousal" and two-flash fusion threshold (TFF), or show changes in TFF under manipulated "arousal" conditions or differences in TFF between groups defined according to "arousal" hypotheses

\section{White noise, instructions, and two-flash fusion with two signal-detection procedures}

a function of the situation, the perion. and the rroup. In . Vew directions in psichologn /II. ew lork: Holt. Rinchart * Winton. 1967. Pp. $111-278$.

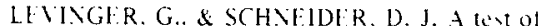
the "risk is a value" hypothesis. Joumal of Personality \& Souial Psychology. 1969. 11. 165-169.

MYERS. D. G. Enhancement of initial risk taking tendencies in social situations. Lnpublished doctoral dissertation. Lniversity of Iowa. 1967.

MYERS. D. G.. IILRDOCH. P.. \& SMITH. G. I. Responsibility diffusion and drive enhancement effects on risky shift. Journal of Personality. in press.

NORDHOY, F. Group interaction in decision-making under risk. Cnpublished Ifaster's thesis. Massachusetts Institute of Technology. 1962

STONER. J. A. F. Risk! and cautious shifts in group decisions: The intluence of widely held values. Journal of Experimental Social Psychology. 1968, 4. 442-459.

TEGER, A. 1.. \& PRLITT. D. G. Components of group risk taking. Journal of Experimental Social Psychology. 1967. 3. 189-205.

VIDMAR, N. Group composition and the risky shift. Journal of Experimental Social Psychology. in press.

WALLACH. M. A.. \& KOGAN, ‥ The roles of information. discussion. and consensus in group risk taking. Journal of Fxperinental Social Psychology. 1965.1. 1-19.

WALLACH. M. A.. \& WING. C. W.. JR. Is risk a value? Journal of Perionality \& Social Psychology. 1968. 9.101-106.

\section{NOTF}

1. This research was supported by a junior faculty research grant to the first author from the Public Health Service and the Liniversity of lowa, a grant (MH-15999-01) to the second author from the National Institute of Mental Health, and an NDEA Title IV fellowship to the third author.
(Venables, 1963a; Rose, 1966. Horn \& Venables, 1964; Hieatt \& Tong, 1969). The psychophysical method used can influence greatly the threshold score (Pearson \& Tong, 1968), and there are indications that forced-choice techniques are essential in that derived scores produce significant results whereas other psychophysical scores fail to reach significance. Clark (1966) has shown that signal-detection procedures are important in perceptual studies with pathological groups. A signal-detection analysis can determine whether differences are the result of criterion placement or sensitivity. Gruzelier \& Corballis (in press) manipulated drugs and instructions in a TFF experiment designed for a signal-detection analysis. The model chosen (Treisman \& Watts, 1966) differs from traditional signal-detection theory (Green $\&$ Swets, 1966), being based on the method of constant stimuli, and appears to 